\title{
PHENOTYPES OF MUTATIONS RELATED TO DEPENDENT SODIUM VOLTAGE CHANNELS ON CHILDREN AND ADOLESCENTS
}

\author{
Andressa Ferreira ${ }^{1}$, Carlos Dias Filho ${ }^{1}$, Nivaldo Junior ${ }^{1}$, Carlos Dias $^{1}$, Sally Cristina ${ }^{1}$, \\ Rafael Andrade ${ }^{1}$, and Cristiano Mostarda ${ }^{1}$ \\ ${ }^{1} \mathrm{UFMA}$
}

July 7, 2020

\begin{abstract}
Cardiac channelopathies are a heterogeneous group of inherited cardiac diseases that are associated with mutations in the genes that encode the expression of cardiac ion channels. In view of this, it can be mentioned that the main hereditary arrhythmias in children and adolescents, caused by dysfunction of the ion channels are Brugada Syndrome (BrS) and Long QT Syndrome (LQTS). However, few studies address the physiological effects of these conditions on children and adolescents. Thus, the aim of this study is to describe the mutation phenotype related to voltage-gated sodium channels in children and adolescents. A search was performed in the literature of Pubmed, Scielo and Google scholar. The search was limited to articles written in English in the last 5 years, so articles published between January 2014 and January 2019 were included. Among 2196 studies identified through a systematic literature review, thirty studies related to the theme were identified for complete review and after applying exclusion criteria 4 articles were included in the results of this research. As the most frequently observed channelopathy, BrS was also more identified in children and adolescents, characterized by episodes of syncope or sudden cardiac death. LQTS shows clinical manifestations with a mild phenotype and good prognosis, although it is necessary to monitor and correct serum electrolyte disturbances to prevent ventricular arrhythmias and, consequently, sudden death in patients with the pathology.
\end{abstract}

\begin{abstract}
:
Cardiac channelopathies are a heterogeneous group of inherited cardiac diseases that are associated with mutations in the genes that encode the expression of cardiac ion channels. In view of this, it can be mentioned that the main hereditary arrhythmias in children and adolescents, caused by dysfunction of the ion channels are Brugada Syndrome (BrS) and Long QT Syndrome (LQTS). However, few studies address the physiological effects of these conditions on children and adolescents. Thus, the aim of this study is to describe the mutation phenotype related to voltage-gated sodium channels in children and adolescents. A search was performed in the literature of Pubmed, Scielo and Google scholar. The search was limited to articles written in English in the last 5 years, so articles published between January 2014 and January 2019 were included. Among 2196 studies identified through a systematic literature review, thirty studies related to the theme were identified for complete review and after applying exclusion criteria 4 articles were included in the results of this research. As the most frequently observed channelopathy, $\mathrm{BrS}$ was also more identified in children and adolescents, characterized by episodes of syncope or sudden cardiac death. LQTS shows clinical manifestations with a mild phenotype and good prognosis, although it is necessary to monitor and correct serum electrolyte disturbances to prevent ventricular arrhythmias and, consequently, sudden death in patients with the pathology.
\end{abstract}

Palavras-chaves Cardiac channelopathies; Voltage-dependent sodium channels; Children; Adolescents. 


\section{INTRODUCTION}

Ion channels are a group of multiple proteins that cross the membrane forming pores or channels $(1,2)$, these proteins are responsible for ionic exchanges between the intracellular and extracellular media, however in some cases the presence of genetic mutations in these channels, also called cardiac channelopathies, are associated with increased risks of cardiac arrhythmias and greater susceptibility to the occurrence of syncope and seizures (3), although, for the most part, there are no underlying structural heart defects (4).

Cardiac channelopathies are a heterogeneous group of inherited heart diseases that are associated with mutations in the genes that encode the expression of cardiac ion channels, these being the $\mathrm{Na}, \mathrm{K}+$ and $\mathrm{Ca} 2$ + channels or proteins that regulate their function (5-7).

In this sense, triggered arrhythmias can be potentially fatal and sudden cardiac death (SCD) is often the first manifestation of these diseases $(8,9)$.

Epidemiological data show that in the western adult population, cardiac canalopathies constitute 1 to $2 \%$ of the most frequently diagnosed predisposing pathologies (10). However, some studies show that cardiac canalopathies are responsible for approximately $1 / 3$ of the cases of SCD in young people and for up to $50 \%$ of cases of arrhythmic SCD in this same population $(1,11)$.

Genetic cardiac arrhythmias are rare in clinical practice, but can have a more severe course, especially in children and adolescents (12). Thus, for the genetic evaluation of patients, with suspicion of this abnormality, their condition and family history must be considered (4).

The genetic panels used in this diagnosis can be general or specific, the first when the individual's clinical condition does not allow an accurate identification of the possible mutation related to a particular gene, the second when the clinical condition allows suspicion of a particular mutation or when there is a previous examination carried out on a family member that indicates the presence of a mutation $(6,11)$.

Given this, it can be mentioned that the main hereditary arrhythmias in children and adolescents, caused by dysfunction of the ion channels are Brugada syndrome (SBr) with an approximate prevalence of 1: 3,300 individuals and the long QT syndrome (LQTS) with prevalence of 1: 2,500 $(8,13)$. However, few studies address the physiological effects of these conditions on children and adolescents.

\section{METHODOLOGY}

\section{Literary review strategies}

A literary review was carried out in order to summarize the results available from the studies found that were related to the theme. To identify the eligible articles, a search was performed in the literature of Pubmed, Scielo and Google scholar. The search was limited to articles written in English in the last 5 years, so articles published between January 2014 and January 2019 were included. We used the following descriptors to search: Cardiac voltage-gated sodium channel; mutations; Cardiac Mutations; Children; and teenagers.

To identify the eligible articles, a search was performed in the literature of Pubmed, Scielo and Google scholar. The search was limited to articles written in English in the last 5 years, so articles published between January 2014 and January 2019 were included. We used the following descriptors to search: Cardiac voltage-gated sodium channel; mutations; Cardiac Mutations; Children; and teenagers.

In addition, reference lists were scanned from retrieved studies to identify any articles that may have been lost in the literature search. The studies included in this review were selected based on the inclusion and exclusion criteria shown in Figure 1.

Figure 1: Flow diagram of research strategy and study selection 


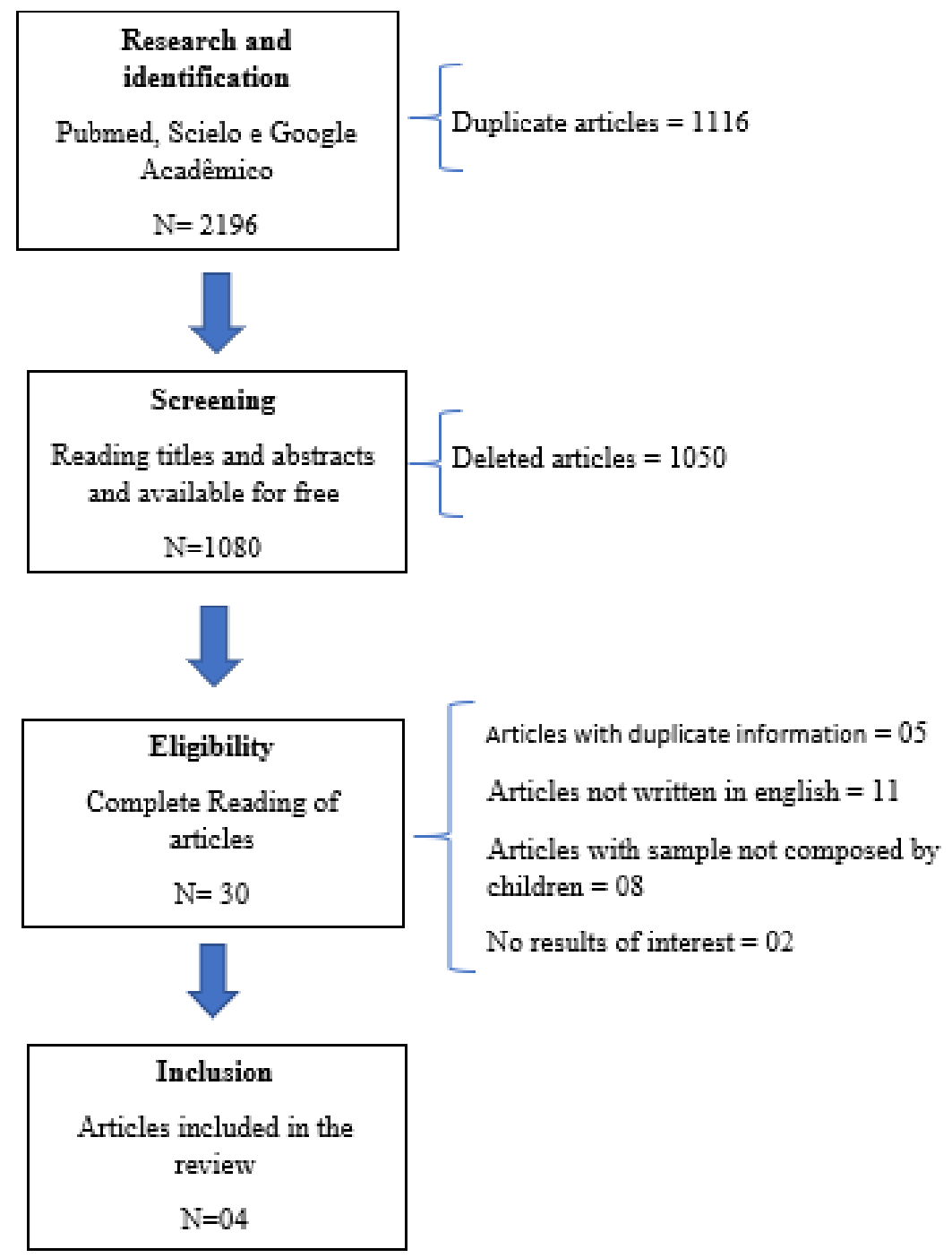

\section{Study Selection Criteria}

To select only the relevant studies, the titles and abstracts of all citations identified by bibliographic research were examined. In this stage, all studies were included who investigated the specific theme: Effect of voltage-dependent sodium channel mutations and aspects related to cardiac muscle in children.

For characterization aspects of the included studies, the following criteria were adopted as the most important: presence of cardiac arrhythmia in children and genetic sodium channel polymorphism. Then, all the necessary data for the characterization were organized and shown in table form. The data that were not identified in the studies were filled in with NE (not evaluated).

\section{RESULTS}

Among the 2196 studies identified through a systematic literature review, thirty studies related to the theme were identified for complete review. Five duplicate articles were excluded, two were not in English, seventeen did not use children or adolescents aged 7 to 14 years in the research sample and two studies had not outcome of interest. Totaling four articles included and characterized in table 1 . The main results of the 
studies included in this review are shown in Table 2.

Table 1 - Characteristics of the study and patients

\begin{tabular}{|c|c|c|c|c|c|}
\hline Author (year) & Study type & Sample & Age & $\begin{array}{l}\text { Patient } \\
\text { Diagnosis }\end{array}$ & $\begin{array}{l}\text { Study } \\
\text { Objective }\end{array}$ \\
\hline $\begin{array}{l}\text { Moreau et al. } \\
(2018)(14)\end{array}$ & Cross analytical & Boys $(n=2)$ & $\begin{array}{l}11 \text { and } 14 \text { years } \\
\text { old }\end{array}$ & $\begin{array}{l}\text { Patient 1: } \\
\text { Brugada Type } 1 \\
\text { Syndrome (BrS) } \\
\text { Patient } 2: \\
\text { Brugada Type } 2 \\
\text { Syndrome (BrS) }\end{array}$ & $\begin{array}{l}\text { Identify a } \\
\text { genetic link } \\
\text { between elec- } \\
\text { tromechanical } \\
\text { atrial } \\
\text { dysfunction and } \\
\text { stroke in children }\end{array}$ \\
\hline $\begin{array}{l}\text { Tsukakoshi et al. } \\
(2018)(15)\end{array}$ & Case study & Girls $(n=1)$ & 13 years old & $\begin{array}{l}\text { Long QT } \\
\text { Syndrome } \\
\text { (LQTS) }\end{array}$ & n.e. \\
\hline $\begin{array}{l}\text { Besli et al. } \\
(2018)(12)\end{array}$ & Case Study & Boy $(\mathrm{n}=1)$ & 9 years old & $\begin{array}{l}\text { Brugada Type } 1 \\
\text { Syndrome (BrS) }\end{array}$ & n.e. \\
\hline $\begin{array}{l}\text { Baskar et al. } \\
(2014)(2)\end{array}$ & Case Study & $\operatorname{Girl}(\mathrm{n}=1)$ & 11 years old & $\begin{array}{l}\text { Possibly } \\
\text { associated with } \\
\text { Brugada } \\
\text { Syndrome Type } \\
1 \text { (BrS) }\end{array}$ & n.e. \\
\hline
\end{tabular}

n.e.: not evaluated.

Table 2 - More results of the studies

\begin{tabular}{|c|c|c|c|c|}
\hline Author (year) & Mutation Type & $\begin{array}{l}\text { Changes } \\
\text { observed on the } \\
\text { electrocardio- } \\
\text { gram }\end{array}$ & $\begin{array}{l}\text { Laboratory } \\
\text { Exams }\end{array}$ & Main Findings \\
\hline $\begin{array}{l}\text { Moreau et al. } \\
(2018)(14)\end{array}$ & $\begin{array}{l}\text { Patient 1: SCN5A } \\
\text { heterozygous } \\
\text { missense mutation } \\
(\mathrm{NM} 198056.2 \text { : } \\
\text { c.3828G }>\text { A, } \\
\text { D1275N). Patient 2: } \\
\text { homozygous } \\
\text { missense mutation } \\
\text { in compound } \\
\text { SCN5A } \\
(\mathrm{NM} 198056.2: \text { c. } \\
3157 \bar{G}>A, \\
\text { E1053K). }\end{array}$ & $\begin{array}{l}\text { Patient 1: Sinus } \\
\text { bradycardia and } \\
\text { paroxymal atrial } \\
\text { flutter. Patient } 2 \text { : } \\
\text { bradycardia ( } 47 \\
\text { bpm) associada a } \\
\text { batimentos } \\
\text { prematuros atriais e } \\
\text { um bloco sinoatrial } \\
2: 1 .\end{array}$ & $\begin{array}{l}\text { No changes in the } \\
\text { blood clotting } \\
\text { system were } \\
\text { detected in both } \\
\text { patients. }\end{array}$ & $\begin{array}{l}\text { This study } \\
\text { evaluated two youg } \\
\text { people with } \\
\text { voltage-gated sodiul } \\
\text { channel mutations } \\
\text { with similar } \\
\text { electrical atrial } \\
\text { dysfunction and } \\
\text { severe stroke. } \\
\text { Emphasizing that } \\
\text { stroke can be } \\
\text { associated with the } \\
\text { mutations. }\end{array}$ \\
\hline
\end{tabular}




\begin{tabular}{|c|c|c|c|c|}
\hline Author (year) & Mutation Type & $\begin{array}{l}\text { Changes } \\
\text { observed on the } \\
\text { electrocardio- } \\
\text { gram }\end{array}$ & $\begin{array}{l}\text { Laboratory } \\
\text { Exams }\end{array}$ & Main Findings \\
\hline $\begin{array}{l}\text { Tsukakoshi et al. } \\
(2018)(15)\end{array}$ & $\begin{array}{l}\text { SLC12A3 A588V } \\
\text { mutation and } \\
\text { SCN5A H558R } \\
\text { polymorphism. }\end{array}$ & $\begin{array}{l}\text { Sinus rhythm with } \\
\text { prolongation of the } \\
\text { QT interval (QT } \\
0.48 \text { seconds, QTc } \\
0.49 \text { seconds), no } \\
\text { other arrhythmia } \\
\text { was recorded on the } \\
\text { Holter ECG. }\end{array}$ & $\begin{array}{l}\text { Hypokalemia ( } 2.7 \\
\mathrm{mEq} / \mathrm{L}) \text {, } \\
\text { hypomagnesaemia } \\
(1.5 \mathrm{mg} / \mathrm{dL}), \text { low } \\
\text { urinary calcium } \\
\text { excretion (U-Ca / } \\
\text { U-Cr 0.0028) and } \\
\text { high level of serum } \\
\text { bicarbonate ( } 28.3 \\
\mathrm{mEq} / \mathrm{L}) .\end{array}$ & $\begin{array}{l}\text { The changes } \\
\text { observed in the } \\
\text { ECG and } \\
\text { laboratory tests are } \\
\text { associated with the } \\
\text { SLC12A3 A588V } \\
\text { mutation and the } \\
\text { SCN5A H558R } \\
\text { polymorphism. } \\
\text { Both related to } \\
\text { mutations in } \\
\text { voltage-gated } \\
\text { sodium channels. }\end{array}$ \\
\hline $\begin{array}{l}\text { Besli et al. (2018) } \\
\text { (12) }\end{array}$ & $\begin{array}{l}\text { Karyotype: } 46, \\
\text { XYqh with minor } \\
\text { polymorphic } \\
\text { deletion in the } \\
\text { heterochromatic } \\
\text { region of the long } \\
\text { arm of the Y } \\
\text { chromosome and } \\
\text { SCN5A } \\
\text { polymorphism } \\
\text { with point } \\
\text { mutation in exon } \\
\text { 11. }\end{array}$ & $\begin{array}{l}\text { Concave type } \mathrm{ST} \\
\text { segment } \\
\text { elevation }>2 \mathrm{~mm} \\
\text { in the right } \\
\text { precordial leads } \\
\mathrm{V} 1 \text { - V2 followed } \\
\text { by negative } \mathrm{T} \\
\text { waves consistent } \\
\text { with BrS type } 1 .\end{array}$ & $\begin{array}{l}\text { Routine } \\
\text { biochemical tests, } \\
\text { electrolytes and } \\
\text { cardiac enzymes } \\
\text { (creatine kinase } \\
\text { MB and troponin } \\
\text { I) within normal } \\
\text { limits. }\end{array}$ & $\begin{array}{l}\text { No family history } \\
\text { consistent with } \\
\text { BrS, although the } \\
\text { parents and } \\
\text { sibling had a } \\
\text { mutation or } \\
\text { polymorphism } \\
\text { similar to that of } \\
\text { the patient. } \\
\text { These changes are } \\
\text { associated with } \\
\text { mutations in } \\
\text { voltage-gated } \\
\text { sodium channels. }\end{array}$ \\
\hline $\begin{array}{l}\text { Baskar et al. (2014) } \\
(2)\end{array}$ & $\begin{array}{l}\text { Heterozygous } \\
\text { mutation in SCN5A } \\
\text { assessed from the } \\
\text { presence of a rare } \\
\text { P1048SfsX97 frame } \\
\text { mutation (c.3142_- } \\
\text { 3153del12ins11) } \\
\text { identified in exon } 17 \\
\text { and missense T220I } \\
\text { mutation (c.659 C> } \\
\text { T). }\end{array}$ & $\begin{array}{l}\text { Exaggerated sinus } \\
\text { arrhythmia and } \\
\text { frequent early atrial } \\
\text { contractions, with a } \\
\text { moderately } \\
\text { prolonged QRS } \\
\text { duration of } 118 \mathrm{~ms} \\
\text { and a normal } \\
\text { corrected QT } \\
\text { interval of } 414 \mathrm{~ms} \text {. }\end{array}$ & n.e. & $\begin{array}{l}\text { Maternal } \\
\text { inheritance of } \\
\text { frameshift mutation } \\
\text { identified with mild } \\
\text { phenotypic } \\
\text { manifestation and } \\
\text { paternal inheritance } \\
\text { of asymptomatic } \\
\text { missense mutation. } \\
\text { Sister of the } \\
\text { heterozygous } \\
\text { patient only for the } \\
\text { frameshift mutation } \\
\text { with mild } \\
\text { phenotypic } \\
\text { manifestation. }\end{array}$ \\
\hline
\end{tabular}

n.e.: not evaluated.

\section{DISCUSSION}


Brugada syndrome (BrS) was first described in 1992 as a new electrical heart disease (16). This is characterized by episodes of syncope or SCD in individuals $<45$ years of age affected by the pathology, and the ECG shows typical elevation of the ST segment in the right precordial leads without the presence of ischemia or structural heart disease (12). However, BrS is definitively diagnosed when elevation of the ST segment is observed, and more than one right precordial ligament in the presence or absence of a sodium channel blocking agent (9).

As the most recurrently observed channelopathy the BrS was also more identified in the studies pointed out in this review in children and adolescents. The diagnosis of $\mathrm{BrS}$ can be difficult in childhood, as it usually manifests as dysrhythmia or SCM (14), in addition, children and adolescents with BrS may have a normal resting ECG, however the presence of fever during a symptomatic episode of the disease could unmask the disease-related changes on the ECG $(12,17)$. In this sense, a previous study of pediatric cases with BrS, approximately half of the syncope events were precipitated by fever (18).

Thus, Besli et al. (2018) in a case study pointed out in this review also evidenced the presence of fever in the patient who presented minor polymorphic deletion in the heterochromatic region of the long arm of the $\mathrm{Y}$ chromosome and SCN5A polymorphism with point mutation in exon 11. Interestingly, although there was no family history consistent with BrS, the patient's parents and sibling presented a mutation or polymorphism similar to that of the patient. Possibly associated with heterozygosis and mild or asymptomatic phenotype of family members.

Moreau et al. (2018) also identified mutations related and consistent with SBr in their case study with an 11year-old child with a heterozygous missense mutation SCN5A and a 14-year-old teenager with a homozygous missense mutation in the compound SCN5A, the individuals were unrelated and both suffered a stroke. In this type of mutation, there is an alteration of one of the DNA bases, in such a way that the nucleotide triplet of which it is part changes, starting to encode an incorrect amino acid with altered function of the synthesized protein (19).

Still on the study by Moreau et al. (2018) the clinical phenotype associated with the first mutation includes several cardiac dysfunctions such as atrial dysfunctions, including sinus node syndrome, atrial arrest and atrial arrhythmias, as well as conduction system disorders. In the second mutation, the E1053K mutation is observed, which is associated with dysfunctions in the ankirin binding protein of Nav1.5, promoting a cardiac arrhythmia caused by altered Nav1.5 function (20). The E1053K mutation eliminates the binding of Nav1.5 to ankirin-G and prevents the accumulation of Nav1.5 at cell surface sites in ventricular cardiomyocytes (20). These mutations that significantly alter the activity and production of important proteins related to cardiomyocyte excitability, they are considered mutations that promote fatal arrhythmias (21). In this case study, the author also associates the presence of mutations in events related to stroke in children and adolescents.

Baskar et al. (2014) observed in his case study changes related to a rare P1048SfsX97 frame mutation that, although it has not yet been reported, this mutation results in loss of sodium channel function, possibly associated with Type 1 Brugada Syndrome. study, the child also had a missense T220I mutation (c.659 $\mathrm{C}>\mathrm{T}$ ). Unlike the previous mutation, it was previously reported and functionally characterized as having multiple effects on the sodium channel, causing general loss of sodium channel function and function of the sinoatrial node pacemaker $(22,23)$.

We can also observe that the SLC12A3 A588V mutation and the SCN5A H558R polymorphism, the only dysfunctions associated with long QT syndrome in the studies included in this review, imply low serum levels of potassium and magnesium, which contribute significantly to the prolongation of the QT interval (24). Although the clinical manifestations of this dysfunction present a mild phenotype and with a good prognosis, life-threatening events can occur even in a rare way (25). Therefore, it is important to monitor and correct serum electrolyte disturbances to prevent ventricular arrhythmias and sudden death in patients with the condition. In the study by Tsukakoshi et al. (2018) the author describes that the H558R polymorphism increases the level of expression of the sodium channel and can therefore affect the initial phase of the action 
potential, however its effects on the QT interval in the present case were unclear.

Thus, the studies included in this review demonstrate the importance of better assessment and elucidation of mutations and polymorphisms related to the cardiovascular system of children and adolescents, once in the last decades an increasing number of studies have described the physiology and changes at the molecular level these dysfunctions, however, few studies have explored the prevalence of these pathologies and their implications in this population. Given this, we found mostly case studies that addressed the theme, but none of them carried out longitudinal monitoring of the individuals reported in the research after diagnosis of the pathologies.

\section{CONCLUSION}

In this literature review, it is possible to observe the main hereditary canalopathies found in children and adolescents from 7 to 14 years old, these being Brugada Syndrome Type 1 and Long QT Syndrome. As the most frequently observed channelopathy, BrS was also more identified in children and adolescents, characterized by episodes of syncope or sudden cardiac death. The second mutation shows clinical manifestations with a mild phenotype and good prognosis, although it is necessary to monitor and correct serum electrolyte disturbances to prevent ventricular arrhythmias and, consequently, sudden death in patients with the pathology.

\section{REFERENCES}

1. Abriel H, Rougier J-S, Jalife J. Ion channel macromolecular complexes in cardiomyocytes: roles in sudden cardiac death. Circulation research. 2015;116(12):1971-88.

2. Baskar S, Ackerman MJ, Clements D, Mayuga KA, Aziz PF. Compound heterozygous mutations in the SCN5A-encoded Nav1. 5 cardiac sodium channel resulting in atrial standstill and His-Purkinje system disease. The Journal of pediatrics. 2014;165(5):1050-2.

3. Hertz CL, Christiansen SL, Larsen MK, Dahl M, Ferrero-Miliani L, Weeke PE, et al. Genetic investigations of sudden unexpected deaths in infancy using next-generation sequencing of 100 genes associated with cardiac diseases. European Journal of Human Genetics. 2016;24(6):817.

4. Fonseca DJ, da Silva MJV. Canalopatias cardíacas: o papel das mutações nos canais de sódio. Revista Portuguesa de Cardiologia. 2018;37(2):179-99.

5. George AL. Inherited disorders of voltage-gated sodium channels. The Journal of clinical investigation. 2005;115(8):1990-9.

6. Cerrone M, Napolitano C, Priori SG. Genetics of ion-channel disorders. Current opinion in cardiology. 2012;27(3):242-52.

7. Clancy CE, Rudy Y. Linking a genetic defect to its cellular phenotype in a cardiac arrhythmia. Nature. 1999;400(6744):566.

8. Ackerman MJ, Zipes DP, Kovacs RJ, Maron BJ. Eligibility and disqualification recommendations for competitive athletes with cardiovascular abnormalities: task force 10: the cardiac channelopathies: a scientific statement from the American Heart Association and American College of Cardiology. Journal of the American College of Cardiology. 2015;66(21):2424-8.

9. Sarquella-Brugada G, Campuzano O, Arbelo E, Brugada J, Brugada R. Brugada syndrome: clinical and genetic findings. Genetics in Medicine. 2016;18(1):3.

10. Mizusawa Y. Recent advances in genetic testing and counseling for inherited arrhythmias. Journal of arrhythmia. 2016;32(5):389-97.

11. Bagnall RD, Weintraub RG, Ingles J, Duflou J, Yeates L, Lam L, et al. A prospective study of sudden cardiac death among children and young adults. New England Journal of Medicine. 2016;374(25):2441-52. 
12. Besli GE, Yıldırım S, Akalın İ, Ayhan Yİ, Kısıŏglu M, Berdeli A. Fever-induced Brugada syndrome in a 9-year-old boy presenting with acute chest pain. The Turkish Journal of Pediatrics. 2018;60(5).

13. Imbrici P, Liantonio A, Camerino GM, De Bellis M, Camerino C, Mele A, et al. Therapeutic approaches to genetic ion channelopathies and perspectives in drug discovery. Frontiers in pharmacology. 2016;7:121.

14. Moreau A, Janin A, Millat G, Chevalier P. Cardiac voltage-gated sodium channel mutations associated with left atrial dysfunction and stroke in children. Ep Europace. 2018;20(10):1692-8.

15. Tsukakoshi T, Lin L, Murakami T, Shiono J, Izumi I, Horigome H. Persistent QT Prolongation in a Child with Gitelman Syndrome and SCN5A H558R Polymorphism. International heart journal. 2018;59(6):1466-8.

16. Sarabanda AVL. Cohort of Patients Referred for Brugada Syndrome Investigation in an Electrophysiology Service-19-Year Registry. Arquivos brasileiros de cardiologia. 2018;111(1):19-20.

17. Brugada P, Brugada J. Right bundle branch block, persistent ST segment elevation and sudden cardiac death: a distinct clinical and electrocardiographic syndrome: a multicenter report. Journal of the American College of Cardiology. 1992;20(6):1391-6.

18. Ching S, Yue CS. Fever-induced Brugada Pattern. The American journal of medicine. 2015;128(11):e29.

19. Geisheker MR, Heymann G, Wang T, Coe BP, Turner TN, Stessman HA, et al. Hotspots of missense mutation identify neurodevelopmental disorder genes and functional domains. Nature neuroscience. 2017;20(8):1043.

20. Mohler PJ, Rivolta I, Napolitano C, LeMaillet G, Lambert S, Priori SG, et al. Nav1. 5 E1053K mutation causing Brugada syndrome blocks binding to ankyrin- $G$ and expression of Nav1. 5 on the surface of cardiomyocytes. Proceedings of the National Academy of Sciences. 2004;101(50):17533-8.

21. Kordeli E, Ludosky M-A, Deprette C, Frappier T, Cartaud J. AnkyrinG is associated with the postsynaptic membrane and the sarcoplasmic reticulum in the skeletal muscle fiber. Journal of cell science. 1998;111(15):2197-207.

22. Olson TM, Michels VV, Ballew JD, Reyna SP, Karst ML, Herron KJ, et al. Sodium channel mutations and susceptibility to heart failure and atrial fibrillation. Jama. 2005;293(4):447-54.

23. Gosselin-Badaroudine P, Keller DI, Huang H, Pouliot V, Chatelier A, Osswald S, et al. A proton leak current through the cardiac sodium channel is linked to mixed arrhythmia and the dilated cardiomyopathy phenotype. PLoS One. 2012;7(5):e38331.

24. Curran ME, Splawski I, Timothy KW, Vincen GM, Green ED, Keating MT. A molecular basis for cardiac arrhythmia: HERG mutations cause long QT syndrome. Cell. 1995;80(5):795-803.

25. Bohnen M, Peng G, Robey S, Terrenoire C, Iyer V, Sampson K, et al. Molecular pathophysiology of congenital long QT syndrome. Physiological reviews. 2016;97(1):89-134. 